\title{
AKTUALISASI NILAI PANCASILA DALAM ACARA ADAT SAMMILAN PADA MASYARAKAT ADAT MAGHO SEKAPPUNG LIBO
}

\author{
Eka Yuliastuti \\ Institut Agama Islam Negeri Metro \\ Jalan Ki Hajar Dewantara, 15 A Metro, Lampung \\ Email: echayoelia@gmail.com \\ Wahyu Abdul Jafar \\ Institut Agama Islam Negeri Bengkulu \\ Jalan Raden Fatah, Pagar Dewa Kota Bengkulu \\ Email:wahyujabar@gmail.com
}

\begin{abstract}
The problem examined in this research is the problem of the actualization of Pancasila values contained in the Sammilan traditional culture and its relevance to the values of local wisdom in the Batin Negara Village. This research belongs to the category of field research, and the approach used in this research is the sociological approach. Data collection techniques used were interview and documentation techniques. After conducting the research, it was concluded that the Sammilan traditional culture contains many positive values that can be applied in living the life of society and the state, the traditional culture of Sammilan is present in the midst of the people who are still very caring and caring for Indonesia in various aspects of life. In carrying out the traditional sammilan event is considered still in harmony and relevant to the values of Pancasila. The tolerance attitude of the people of Sekappung Libo is reflected if there are neighbors who are carrying out an adat event, they are not afraid without being asked to respect each other, help each other and help one another.
\end{abstract}

Keywords: Actualization of Pancasila Values; Indigenous Sammilan

\begin{abstract}
Abstrak: Permasalahan yang dikaji dalam penelitian ini adalah persoalan aktualisasi nilai-nilai Pancasila yang terkandung dalam budaya adat Sammilan serta relevansiya dengan nilai-nilai kearifan local yang ada di Desa Negara Batin. Penelitian ini termasuk kategori field research (penelitian lapangan), dan pendekatan yang digunakan dalam penelitian ini adalah pendekatan sosiologis. Teknik pengumpulan data yang dipergunakan adalah teknik wawancara dan dokumentasi. Setelah melakukan penelitian diperoleh kesimpulan bahwa Budaya adat Sammilan mengandung banyak nilai positif yang dapat diterapkan dalam menjalani kehidupan bermasyarakat maupun bernegara, budaya adat Sammilan hadir ditengah-tengah masyarakat yang masih sangat menjaga dan memelihara Indonesia dalam berbagai aspek kehidupan. Dalam melaksanakan acara adat sammilan dinilai masih selaras dan relevan dengan nilai-nilai pancasila. Sikap toleransi warga adat sekappung libo tercermin apabila ada tetangganya yang sedang melaksanakan suatu acara adat, tak segan tanpa diminta mereka akan saling menghargai, saling membantu, dan tolong menolong.
\end{abstract}

Kata kunci: Aktualisasi Nilai Pancasila; Adat Sammilan; 


\section{Pendahuluan}

Dalam kehidupan berbangsa, Pancasila $^{1}$ selain berfungsi sebagai

Dasar dan Lambang Negara juga berfungsi sebagai Ideology Bangsa. Pancasila adalah perumusan dari pedoman kehidupan berbangsa dan bernegara bagi seluruh rakyat Indonesia. Pancasila sebagai norma dasar yang digagas oleh Founding father yang kemudian dirumuskan kedalam 8 pengertian oleh Dharmodiharjo $^{2}$, antara lain sebagai berikut :

1. Pancasila sebagai jiwa bangsa Indonesia

2. Pancasila sebagai kepribadian bangsa Indonesia

3. Pancasila sebagai pandangan hidup bangsa Indonesia

\footnotetext{
${ }^{1}$ Pancasila adalah salah satu produk dari manifestasi dari teori Trias politica. Yakni teori yang beranggapan bahwa kekuasaan negara terdiri atas tiga macam kekuasaan: Pertama, kekuasaan legislatifatau kekuasaan membuat undang-undang (rule making function); kedua, kekuasaan eksekutif atau kekuasaan melaksanakan undang-undang (rule application function); ketiga kekuasaan yudikatif atau kekuasaan mengadili atas pelanggaran undangundang (rule adjudication function). Wery Gusmansah, Triaspolitika dalam perspektif fiqh syiasah, Jurnal Imaroh, Vol 2 No 2 Tahun 2017, h. 124

${ }^{2}$ Darji Darmodiharjo, Shidarta. Pancasila (Penjabaran nilai-nilai pancasila dalam sistem hukum Indonesia), Jakarta : Raja Grafindo Persada, 1996, h. 11
}

4. Pancasila sebagai dasar Negara Republik Indonesia

5. Pancasila sebagai sumber dari segala sumber hokum atau sebagai sumber tertib hokum baga Negara Indonesia

6. Pancasila sebagai perjanjian luhur bangsa Indonesia

7. Pancasila sebagai cita-cita dan tujuan bangsa Indonesia

8. Pancasila sebagai filsafat hidup bangsa

Nilai nilai pancasila ini juga terlihat pada Falsafah hidup masyarakat lampung sejak terbentuknya masyarakat adat adalah Piil Pesinggiri. Pill dalam bahasa arab (fiil) artinya adalah perilaku sedangkan pesinggiri adalah mempunyai nilai moral yang tinggi, memiliki jiwa yang besar, bisa menempatkan diri, mengerti antara yang hak dan yang wajib. Piil Pesinggiri mempunyai pengertian sebagai sudut pandang atau cara hidup suatu masyarakat yang digunakan untuk pedoman hidup didalam tata cara pergaulan supaya kerukunan hidup, kesejahteraan serta keadilan dapat terlihat. $^{3}$

${ }^{3}$ Risma Margareta Sinaga, "Revitalisasi Tradisi: Strategi Mengubah Stigma Kajian Piil Pesenggiri dalam Budaya Lampung”, dalam 
Eka Yuliastuti dan Wahyu Abdul Jafar:

Dikecamatan Jabung, ada masyarakat adat yang bernama Magho Sekappung Libo. Masyarakat adat Magho Sekappung Libo ini dikepalai oleh seorang penyimbang adat dan beberapa pembantu penyimbang adat. Acara adat yang sampai sekarang masih melekat dan dilakukan oleh masyarakat adat Magho Sekappung Libo yaitu adat Sammilan atau ngambil gadis. Adat Sammilan atau ngambil gadis adalah adat utama yang harus ditempuh sebelum menyelesaikan acara pernikahan hingga acara pernikahan selesai dilaksanakan. Adat ini dilakukan oleh masyarakat Jabung khususnya di desa Negara Batin dalam suatu upacara pernikahan. Pelaksanaan Adat Sammilan ini biasanya dilakukan oleh mereka yang masih mempunyai keturunan adat. Dalam pelaksaan Adat Sammilan ini juga terdapat suatu istilah yang di sebut dengan sakaian atau gotong royong dan istilah khagom yang berarti kompak atau bersatu.

Dari hasil survey yang peneliti lakukan, terdapat beberapa hal yang sangat menarik ketika dikaitkan antara praktek yang terdapat dalam acara adat

Masyarakat Indonesia, Jurnal vol. 40 (Juni 2014), h. 109-110
Sammilan di Desa Negara Batin Kecamatan Jabung Lampung Timur, dengan nilai-nilai yang terkandung dalam Pancasila khususnya sila ke 4, yaitu Kerakyatan yang di pimpin oleh hikmat kebijaksanaan dalam permusyawaran/perwakilan dan sila ke 5, yaitu Keadilan social bagi seluruh rakyat Indonesia, yaitu adanya suatu kesepakatan yang diambil melalui cara musyawarah mufakat dan gotong royong. Berdasarkan hasil wawancara dengan penyimbang adat Maggo Sekappung Libbo desa Negara Batin, yang peneliti lakukan Seberapa banyak praktek musyawarah mufakat dan gotong royong yang terdapat dalam acara adat Sammilanini relevan dengan nilai-nilai pancasila tersebut, nantinya akan peneliti tuangkan melalui penelitian yang lebih dalam dengan judul Aktualisasi Nilai Pancasila Dalam Acara Adat Sammilan Pada Masyarakat Adat Magho Sekappung Libo.

Berdasarkan latar belakang masalah datas, dapat dirumuskan permasalahan sebagai berikut :

1. Bagaimana wujud aktualisasi nilainilai kearifan local yang terkandung dalam budaya adat Sammilan yang ada di Desa Negara Batin? 
2. Bagaimana relevansi aktualisasi nilai-nilai kearifan local yang terkandung dalam budaya adat Sammilan dengan nilai-nilai Pancasila yang terjadi di Desa Negara Batin?

\section{Metode Penelitian}

Penelitian ini termasuk kategori penelitian field reseach tepatnya dilakukan di desa Negara Batin Kecamatan Jabung Kabupaten Lampung Timur. Penelitian ini mendiskripsikan aktualisasi nilai nilai pancasila pada acara adat Sammilan, dimana terdapat praktek Musyawarah Mufakat serta Gotong Royong yang dilakukan oleh masyarakat setempat. Penelitian ini mengarah pada perkembangan nilai-nilai pancasila dalam kearifan local masyarakat dengan mengunakan pedekatan sosiologis.

\section{Data Penelitian}

Data primer dalam penelitian ini adalah penyimbang adat, pemerintah/aparat birokrat, masyarakat adat magho sekappung libo, tokoh pemuda di desa Negara Batin Kecamatan Jabung Kabupaten Lampung Timur. Sedangkan data sekunder dalam penelitian ini adalah buku tentang pancasila, kearifan lokal, hasil penelitian, artikel, makalah, jurnal baik dalam maupun luar negeri.

\section{Teknik Pengumpulan Data}

Untuk memperoleh data primer dan data sekunder sebagaimana dikemukakan diatas, maka teknik pengumpulan data dilakukan dengan cara, yakni wawancara dan dokumentasi. Wawancara dilakukan secara terstruktur dengan ruang lingkup atau orientasi jawaban menyangkut isi atau substansi tentang nilai-nilai pancasila yang selaras dengan nilai adat yang berlaku pada masyarakata adat Magho Sekappung Libo.

Dalam mengumpulkan data, Peneliti menggunakan teknik purposive sampling. Kreteria dalam pemilihan informan adalah informan harus memiliki kredibilitas dan mengetahui atau menjadi pelaku Adat Magho Sekappung Libo. Wawancara dilakukan secara terbuka, dipandu dengan daftar pertanyaan yang runtun secara rasional guna menggali opini subyek yang diteliti tentang permasalahan dalam penelitian ini.

Setelah semua data terkumpul kemudian dianalisa. Model analisis yang digunakan adalah model analisis interaktif (interaktif model of analisis) 
Eka Yuliastuti dan Wahyu Abdul Jafar:

dari Miles dan Huberman, yakni analisis yang diawali sejak dilakukannya pengumpulan data, dengan cara membuat tiga komponen (reduksi data, sajian data, kesimpulan).

\section{Teori Kearifan Lokal}

Kearifan lokal dalam beberapa tahun belakangan ini sangat sering diperbincangkan. Perbincangan tentang kearifan lokal sering dikaitkan dengan masyarakat lokal. Kearifan lokal dalam bahasa asing sering diartikan sebagai kebijakan setempat (lokalwisdom), pengetahuan setempat (knowledge wisdom)atau kecerdasan setempat(local genius). ${ }^{4}$ Kearifan lokal terdiri dari dua kata, yaitu kearifan (wisdom) dan lokal (local). Dalam kamus bahasa Inggrisindonesia, local berarti tempat sedangkan wisdom (kearifan) berartikebijaksanaan. Secara umum maka dapat dipahamilocal wisdom (kearifan setempat) sebagai gagasangagasan setempat (local) yang bersifat yang bersifat bijaksana, penuh kearifan,

\footnotetext{
${ }^{4}$ Soerjanto Poespowardojo, Pengertian Genius Lokal serta Relevansinya Dalam Modernisasi, "Dalam Kepribadian Budaya Bangsa (lokal Genius), by Ayatrohaedi, Pustaka Jaya, Jakarta,1986,h. 100-101
}

bernilai baik, yang tertanam dan di ikuti oleh anggota masyarakatnya. ${ }^{5}$

Kearifan lokal juga dapat diartikan sebagai pandangan hidup dan pengetahuan serta berbagai strategi kehidupan yang berwujud aktifitas yang dilakukan oleh masyarakat lokal dalam menjawab berbagai masalah dalam pemenuhan kebutuhan mereka. Sistem pemenuhan kebutuhan mereka pasti memenuhi seluruh unsur kehidupan; agama, ilmu pengetahuan, ekonomi, teknologi, sosial, bahasa, komunikasi,serta budaya. Mereka mempunyai pemahaman, program kegiatan, pelaksanaan terkait untuk mempertahankan, memperbaiki dan mengembanghkan unsur kebutuhan dan cara pemenuhannya, dengan memperhatikan sumber daya manusia dan sumberdaya alam sekitarnya. ${ }^{6}$

Dalam artikel berjudul "Melestarikan Kearifan Masyarakat Tradisional (Indegenous Knowledge)”, menyatakan bahwa pada dasarnya setiap komunitas masyarakat memiliki kearifan lokal (lokal wisdom).Kearifan

\footnotetext{
${ }^{5}$ John M.Echols dan Hasan syadily, Kamus Bahasa Inggris-Indonesia, PT. Gramedia Pustaka Utama, 2008, h. 12

${ }^{6}$ Abdul Syani, Nilai-Nilai Budaya Bangsa dan kearifan Lokal, http://staff.unila.ac.id, di unduh tanggal 12 April 2019
} 
lokal yang terdapat pada komunitas masyarakat tradisional sekalipun terdapat suatu proses menjadi pintar dan berpengetahuan (being smart and knowledgeable). Halini berkaitan dengan adanya keinginan agar dapat mempertahankan dan melangsungkan kehidupan,sehingga warga komunitas masyarakat akan secara spontan memikirkan cara-cara untuk melakukan dan/atau menciptakan sesuatu. Pengembangan suatu sistem pengetahuan dan teknologi yang asliitulah yang disebut dengankearifan lokal. ${ }^{7}$

Kebudayaan yang sudah melekat dimasyarakat dan sudah turun temurun sejak jaman dulu, akan semakin terkonsep dalam kehidupan masyarakat sehingga menjadi sebuah kepercayaan terhadap suatu hal yang berhubungan dengan keyakinan dan sulit untuk dihilangkan. Kepercayaan-kepercayaan yang ada dan masih berkembang dalam kehidupan suatu masyarakat, biasanya bisa dipertahankan melalui sifat-sifat local yang dimilikinya. Dimana sifat local tersebut pada akhirnya dapat menjadi suatu kearifan yang akan selalu

${ }^{7}$ Fx Haryono, Kearifan Budaya Dalam Kata, Edisi Revisi, PT Wedatama Widya Sastra, 2015, h. 10 dipegang teguh oleh masyarakatnya. Nilai-nilai kearifan local yang masih ada biasanya masih dipertahankaan oleh masyarakat yang masih memiliki tingkat kepercayaan yang kuat.Kepercayaan yang masih menjadi tradisi dalam masyarakat juga disebabkan karena kebudayaan yang ada biasanya bersifat universal sehingga kebudayaan tersebut telah melekat pada masyarakat dan sudah menjadi hal yang pokok dalam kehidupan bermasyarakat. ${ }^{8}$

Kearifan lokal mempunyai hubungan yang sangat erat dengan kebudayaan tradisional suatu daerah. Dalam kearifan lokal banyak terkandung suatu pandangan ataupun aturan supaya masyarakat lebih memiliki pijakan dalam menentukan sebuah tindakkan seperti prilaku hidup masyarakat sehari-hari. Pada dasarnya nilai moral maupun etika yang terkandung dalam kearifan lokal diajarkan secara turun-temurun, dan diwariskan dari generasi ke generasi melalui sastra lisan (diantaranya dalam bentuk pepatah dan peribahasa, folklore), serta manuskrip. Nilai

\footnotetext{
${ }^{8}$ R.Cecep Eka Permana, Kearifan Lokal Masyarakat Baduy dalam Mitigasi Bencana, PT Wedatama Widya Sastra, 2010, h. 23
} 
Eka Yuliastuti dan Wahyu Abdul Jafar:

kearifan lokal yang diajarkan secara turun-temurun merupakan kebudayaan yang patut untuk dijaga oleh masingmasing wilayah yang memiliki satu atau lebih kebudayaan sebagai ciri khasnya dan terdapat nilai kearifan lokal yang terkandung di dalamnya. Pembentukan dan perkembangan budaya sangat mempengaruhi jati diri suatu bangsa, kesatuan masyarakat berperan serta dalam upaya pembentukkannya.

Konsep kearifan lokal atau kearifan tradisional atau sistem pengetahuan lokal (indigenous knowledge system) adalah pengetahuan yang khas milik suatu masyarakat atau budaya tertentu yang telah berkembang lama sebagai hasil dari proses hubungan timbal balik antara masyarakat dengan lingkungannya. ${ }^{9}$ Jadi, konsep sistem kearifan lokal berakar dari sistem pengetahuan dan pengelolaan lokal maupun tradisional.

Masing-masing wilayah yang ada di Indonesiamempunyai ciri atau ke Khasan dari kebudayaannyasehingga wajib dilestarikanserta dirawatagar identitas bangsa tetap terjaga dan masih bisa

\footnotetext{
${ }^{9}$ Marzali, dalam Munfangati, dkk, Kearifan Lokal di Lingkungan Masyarakat Samin Kabupaten Blora Jawa Tengah, 2004, Yogyakarta, Kementrian Kebudayaan dan Pariwisata, h. 21.
}

terus dikembangkan oleh generasi selanjutnya.

Koentjaraningrat mengatakan bahwa kebudayaan nasional Indonesia berfungsi sebagai pemberi identitas kepada sebagian warga dari suatu nasion, merupakan kontinyuitas sejarah dari jaman kejayaan bangsa Indonesia di masa yang lampau sampai kebudayaan nasional masa kini. Masyarakat memiliki peranan penting dalam pembentukan budaya agar terus bertahan diperkembangan jaman, baik secara langsung maupun tidak langsung dengan memanfaatkan kemampuannya, sehingga manusia mampu menguasai alam.Selo Soemardjan dan Soelaeman Soemar dalam buku Soerjono Soekanto ${ }^{10}$, merumuskan kebudayaan sebagai hasil karya, rasa, dan cipta masyarakat.Karya masyarakat menghasilkan teknologi dan kebudayaan kebendaan atau kebudayaan jasmaniah (material culture) yang diperlukan oleh manusia untuk menguasai alam sekitarnya agar kekuatan serta hasilnya dapat diabdikan untuk keperluan masyarakat.

\footnotetext{
${ }^{10}$ Selo Soemardjan dan Soelaeman Soemar dalam buku Soerjono Soekanto, Sosiologi Suatu Pengantar (Edidi Revisi)PT. Rajawali Pers, 2013, h. 55
} 
Berbagai aneka ragam kebudayaan suatu wilayah melahirkan kekuatan yang dapat dipergunakan untuk membangun kekuatan serta gambaran adat sendiri di setiap wilayah tersebut, sehingga menjadikannya bagian yang penting dalam terbentuknya kekuatan serta gambaran adat yang ada disuatu wilayah tertentu. Lain daripada itu, keberagaman yang ada adalah hasil sebuah gagasan yang cerdas dimana kebudayaan yang tumbuh dan berkembang dimasyarakat wajib untuk selalu dijaga serta dilestarikan keberadaannya. Sejalan dengan pengembangan technology serta modifikasi kebudayaan menuju ke kehidupan yang lebih moderen diimbangi dengan masuknya pengaruh arus global yang semakin pesat, sehingga aset kebudayaan maupun nilai konservatif suatu daerah adat mengalami sebuah hal yang menantang bagi keberlangsungannya. Semua ini ini harus dikaji karena aset kebudayaan dan nilai-nilai tradisi tersebut didalamnya terkandung nilai kearifan lokal yang relevan dengan kondisi serta situasi masyarakat saat ini, dan dapat dilestarikan, disesuaikanbila perlu dapat berkembangjauh dan mendalam lagi.

\section{Aktualisasi Nilai-Nilai Pancasila}

Aktualisasi merupakan suatu bentuk kegiatan dalam melakukan realisasi terhadap nilai dan norma dengan tindakan dan perbuatan yang dilakukan dalam kehidupan sehari-hari. Sedangkan aktualisasi Pancasila berarti penjabaran nilai-nilai Pancasila dalam bentuk norma-norma, serta merealisasikannya dalam kehidupan berbangsa dan bernegara. Dalam aktualisasi nilai-nilai Pancasila, penjabaran nilai-nilai Pancasila kedalam bentuk norma-norma sering dijumpai dalam bentuk norma hukum, dan norma moral. Sedangkan realisasinya dikaitkan dengan tingkah laku semua warga dalam bermasyarakat,berbangsa dan bernegara.

Masyarakat Indonesia terkenal santun dalam berperilaku, mempunyai kearifan lokal yang kaya dan pluralis, melaksanakan musyawarah mufakat dalam menyelesaikan masalah dan hidup secara bergotong royong. Pancasila selain sebagai pandangan hidup bangsa Indonesia, juga menjadi dasar warga negara dalam hidup bermasyarakat dan beperilaku dalam kehidupan sehari-hari. Aktualisasi Pancasila dibedakan dalam 2 macam, 
Eka Yuliastuti dan Wahyu Abdul Jafar:

yaitu aktualisasi yang obyektif dan subyektif, ${ }^{11}$ :

1. Aktualisasi Pancasila yang Obyektif

Aktualisasi Pancasilayang obyektif yaitu aktualisasi Pancasila dalam berbagai bidang kehidupan yang meliputi, kelembagaan Negara antara lain, Eksekutif, Yudikatif, dan Legislatif, selain itu jyga meliputi bidang aktualisasilainnya, seperti Politik, Hukum dan Ekonomi, Pertahanan keamanan ,pendidikan maupun bidang kenegaran lainnya.

2. Aktualisasi Pancasila Yang Subyektif

Aktualisasi Pancasila yang subyektif adalah pedoman pelaksaannya dirumuskan oleh MPR, Tap.No.II/MPR/1978, tentang Eka Prasetya Pancakarsa, yang berarti tekad tunggal untukmelaksanakan lima kehendak. Lima kehendak tersebut adalah kelima sila Pancasila yang sudah dikendaki bangsa Indonesia sebagai ideologi bangsa dan negara .

Ms Noor Bakery ${ }^{12}$ mengatakan bahwa apabila diperhatikan, suatu bangsa dapat hidup dan berkembang

\footnotetext{
${ }^{11}$ Noor Ms Bakry, Pendidikan Pancasila, Pustaka Pelajar, Yogyakarta,2014, h. 291

${ }^{12}$ Ms Noor Bakery, Pendidikan Pancasila, Pustaka Pelajar, yogyakarta, 2014, h. 292
}

dengan integritas dan kepribadian yang kuat apabila memiliki pandangan hidup yang dapat dimengerti, dihayati serta diamalkan didalam kehidupan seharihari oleh seluruh warga negaranya. Adapun jiwa dan kepribadian yang menjadi pandangan hidup bangsa Indonesia adalah Pancasila yang diakui secara formal sebagaidasar negara Indonesia sepertitercantum dala Pembukaan UUD1945.

Pada masa globalisasi seperti saat ini permasalahanyang cukup gentingserta

harusmendapatkanperhatian khusus adalah terkait dengan identitas bangsa. Makin derasnya arus globalisasi mengakibatkan tergerusnya nilai budaya bangsa. Generasi muda lebih bangga dengan budaya asing daripada budaya lokal bangsaIndonesia. Hal ini semakin dibuktikan dengan adanya rasa bangga yang berlebih pada diri anak manakala mereka menggunakan produk luar negeri, dibandingkan jika mereka menggunakan produk bangsaIndonesia. Slogan "aku cinta buatan Indonesia" sepertinya hanya menjadi sekedar ucapan, tanpa ada aksi nyata yang mengikuti pernyataan tersebut. 
Keberadaan kearifan lokal ini bukan tanpa fungsi. Kearifan lokal sangat banyak fungsinya. Seperti yang dikatakan oleh Sartini ${ }^{13}$, bahwa fungsi kearifan lokal adalah sebagai berikut:

- Berfungsi untuk konservasi dan pelestarian sumber daya alam.

- Berfungsi untuk pengembangan sumber daya manusia.

- Berfungsi untuk pengembangan kebudayaan dan ilmu pengetahuan.

- Berfungsi sebagai petuah, kepercayaan, sastra dan pantangan.

- Bermakna sosial misalnya upacara integrasi komunal/kerabat.

- Bermakna sosial, misalnya pada upacara daur pertanian.

- Bermakna etika dan moral

- Bermakna politik, misalnya upacara ngangkuk merana dan kekuasaan patron client.

Permasalahan budaya lokal sebagai falsafah hidup yang ada jauh sebelum lahirnya Pancasila dan karakter bangsa kini telah banyak menjadi sorotan tajam oleh masyarakat.Sorotan itu mengenai banyaknya budaya asing yang masuk ke Indonesia yang membuat budaya atau

${ }^{13}$ Sartini, Menggali Kearifan Loka Nusantara : Sebuah Kajian Filsafati, Jurnal Filsafati, Vol.14, Universitas Gajah Mada, 2004, h. 111-120 nilai-nilai kehidupan masyarakat Indonesia khususnya yang ada di Lampung semakin ditinggalkan dan nilai-nilai modern yang masuk ternyata belum dapat diadopsi secara sempurna oleh masyarakat sehingga mengakibatkan banyaknya manusia yang berkepribadian pecah. Hal ini tertuang dalam berbagai media baik media cetak maupun media elektronik.Selain itu juga banyak dibicarakan di diskusi, dan seminar oleh para pemuka masyarakat, para ahli, para pendidik, para budayawan, dan para pengamat sosial baik pada tingkat lokal dan tingkat nasional. Pembangunan karakter bangsa memang bukanlah tanggung jawab persekolahan saja tetapi juga masyarakat dan keluarga.

Atas dasar kenyataan itu, maka perlu pernikiran ulang kontekstualisasi nasionalisme Indonesia dan nilai-nilai kearifan lokal.Pemikiran ini bisa ditindaklanjuti melalui pembangunan karakter berbasis nilai-nilai budaya daerah.Tujuannya adalah untuk menemukan kembali nilai-nilai kearifan lokal sebagai sumber daya untuk menumbuhkan nasionalisme bangsa Indonesia.Hal ini diharapkan dapat menjadi sumber inspirasi seluruh 
Eka Yuliastuti dan Wahyu Abdul Jafar:

bangsa, agar lebih mengutamakan kepentingan rakyat, bangsa dan negara.

Nasionalisme dapat diartikan sebagai rasa kebanggaan, rasa memiliki, rasa menghargai, rasa menghormati dan loyalitas yang dimiliki oleh setiap individu pada negara tempat ia tinggal yang tercermin dari perilaku membela tanah airnya, menjaga dan melindungi tanah airnya, rela berkorban demikepentinganbangsadannegaranya.

\section{Karakteristik Nasionalisme}

melambangkan kekuatan suatu negara dan aspirasi yang berkelanjutan, yaitu mengupayakan peningkatan kemakmuran, pemeliharaan rasa hormat, membanggakan pribadi bangsa dan sejarah kepahlawanan suatu negara, pembelaan kaum patriot dalam melawan pihak asing, memiliki hubungan kepercayaan dengan nilai-nilai tradisi, lambang nasionalisme diberikan untuk sebuah kesucian, dan penghargaan hukum.

Dalam proses kompromi budaya, kearifan lokal bukan hanya berfungsi menjadi filter ketika terjadi benturan antara budaya lokal dengan tuntutan perubahan. Lebih jauh, nilai-nilai budaya lokal berbicara pada tataran penawaran terhadap sumberdaya nilai- nilai kearifan lokal sebagai pedoman moral dalam penyelesaian masalah ketika sebuah kebudayaan berhadapan dengan pertumbuhan antagonis berbagai kepentingan hidup.

Pembahasan: Wujud Aktualisasi Nilai-Nilai Kearifan Lokal Yang Terkandung Dalam Budaya Adat Sammilan

Perwujudan nilai-nilai pancasila dalam hidup bernegara dituangkan dalam hukum dasar negara yang merupakan penjelmaan pokok-pokok pikiran yang berkaitan dengan pengamalan Pancasila dalam kenegaraan sebagai bentuk aktualisasi nilai-nilai Pancasila.

Aktualisasi nilai-nilai Pancasila dalam kehidupan, dalamarti betul-betul terjadi dalam kenyataan terwujud dalam pengamalan. Pengamalan pancasila ada dua macam, pengamalan subjektif Pancasila, yaitu pelaksanaan pancasila sebagai filsafat yang kemudian hidup dan berkembang didalamkehidupan warga Negara Indonesia, serta pengamalan yang objektif dari Pancasila, yaitu cara mengamalkan Pancasila dalam sistem kenegaraan dan penyelenggaraan pemerintahan negara.

Tata Cara Mengambil Gadis 
Ada dua cara mengambil gadis yang dilakukan oleh warga adat sekappung libo, diantaranya yaitu :

\section{Mengambil gadis dengan cara ngebummang/Larian}

Mengambil gadis dengan cara ngebummang adalah mengambil gadis dengan cara membawa lari si gadis tanpa diketahui oleh orang tua atau keluarga pihak gadis tetapiumeninggalkan pelarian berupa surat pemberitahuan oleh sigadis dan dau ngawitan.

\section{Mengambil gadis dengan cara sammilan / Terang}

Mengambil gadis dengan cara sambilan adalah mengambil gadis dengan cara berunding antara orang tua sibujang dan orang tua sigadis melalui seorang celumut atau utusan.

Wujud nilai kearifan lokal yang masih melekat pada masyarakat adat Magho Sekappung Libo salah satunya dalamhal ini tata cara mengambil gadis dengan cara Sammilan yang masih menarik untuk diteliti karena masih terdapat nilai-nilai kearifan lokal didalamnya dalamyaitu dalam wujud musyawarah mufakat dan gotong royong yang masih selaras dengan nilai- nilai Pancasila yang ada dan berlaku pada masyarakat Indonesia.

Mengambil gadisdengan cara Sammilan ini dilakukan dengan cara musyawarah mufakat dimana pihak dari keluarga laki-laki datang ke rumah pihak keluarga perempuan yang biasanya kedatangan mereka didampingi dengan penyimbang adat dan beberapa pembantu penyimbang adat dari masing-masing pihak keluarga. Dalam hal ini musyawarah mufakat yang dilakukan adalah bertujuan untuk menentukan besaran uang yang harus diberikan pihak lakilaki kepada pihak perempuan sebelumupacara pernikahan dilaksanakan.

Menurut Dalom Sempurna Jaya Nur selaku penyimbang adat 3 yang ada di desa negara batin, apabila salah satu dari warga adat desa negara batin, ingin mengambil gadis dari desa negara batin atau desa lain misalnya negara saka atau desa jabung, maka wajib datang kerumah pihak perempuan keluarga laki-laki yang akan mengambil gadis tersebut dengan didampingi masingmasing penyimbang adat dari desa tersebut. Demikian juga dirumah si gadis, telah berkumpulkeluarga dan 
Eka Yuliastuti dan Wahyu Abdul Jafar:

penyimbang adat. ${ }^{14}$ Hal ini bertujuan demi terwujudnya musyawarah mufakat sehingga dikemudian hari tidaklagimenjadi perdebatan adanya besaran biaya yang akan diberuikan oleh keluarga laki-laki kepada keluarga perempuan.

Musyawarah mufakat biasanya dilakukan tidak hanya sekali saja, tetapi bisa 2 atau 3 kali sampai terjadi kesepakatan pemberian uang yang yang diminta oleh pihak perempuan dan sejauh mana pihak keluarga laki-laki menyanggupi permintaan uang dari pihakperempuan tersebut. Berbeda dengan adat ngebummang atau larian, dimana di adat ngebummang atau larian tidak ada musyawarah mufakat antara kedua belah pihak, karena pihak lakilaki langsung membayar denda adat kemudian membawa lari si gadis.

Tata cara mengambil gadis melalui budaya sammilan ini jika ditelaah masih sesuai dan selaran dengan nilai-nilai pancasila yaiyu sila ke 4 dan sila ke 5 . Oleh sebab itu masayarakat adat magho sekappung libo masih banyak yang mempertahankan keberadaan adat Sammilan ini, apalagi jika pernikahan

14 Wawancara dengan Dalom Sempurna Jaya Nur, penyimbang Adat Desa Negara Batin , tanggal 17 agustus 2019 tersebut terjadi dengan orang yang berada diluar suku magho sekappung libo, maka adat sammilan ini menjadi alternatif yang diambiluntuk tercapainya ksepekatan sebelum acara pernikahan dilaksanakan.

Setelah mengambil gadis selanjutnya diadakan kegiatan Magho Suku atau Meghasukum. Magho Suku adalah serangkaian acara adat yang harus ditempuh dalam menyelesaikan acara perkawinan hingga acara tersebut selesai dilaksanakan. Adapun langkahlangkah yang harus ditempuh dalam acara Magho Suku antara lain :

a. Menunjuk Clumut/Utusan

Tugas Clumut atau Utusan antara lain :

- Menyampaikan waktu pelaksanaan penyelesaian adat kepada pihak keluarga bujang (bekas ngayonan).

- Menyampaikan status adat yang akan didudukkan kepada kedua mempelai khususnya dan umumnya kepada kedua keluarga.

- Ada beberapa kemungkinan adat yang akan dipilih dalam maghosuku, antara lain: adat ngelepasi, adat ngejujor/beli, adat ngisik, dan adat cammor suami/jajagh bubungan. 
- Pihak pengantin laki-laki mengantar prabio/biaya

- Prabio bisa berupa prabio mentah atau prabio tasak.

- Prabio tasak atau mateng berupauang, sedangkan prabio mentah bisa berupa barang, seperti : roti 12 macam, minyak kelapa dan minyak lampu, beras biasa dan beras ketan, kepala, kayu masak, daun pisang, taliwaru, alat bumbu masak secukupnya,kambing hidup, kambing mati, rokok, tembakau, seperangkat alat penerangan/lampu.

- Ngumpulan meranai/bujang, yaitu kumpulan para bujang untuk memberitahukan untuk memberitahukan acara maghosuku yang dipimpin oleh seorang kepala bujang.

- Maghosuku adalah mengantarkan pengantin laki-laki ketempat pengantin perempuan untuk sidang adat penyimbang dengan menyelesaikan adatnya. Pada waktu yang sama sekaligus menyerahkan dau adatnya kepadasuku-suku.

- Sujud pengantin laki-laki kepada para peniymbang adat dan keluarga besar yang ada dipihak perempuan dan diteruskandengan sujud pesabaian.

a. Sujud pengantin adalah, pengantin laki-laki melakukan sujud kepada penimbang adat, kedua orangtuang dan seluruh keluarga dari pihak pengantin perempuan.

Dalam acara adat Sammilan ini selain terdapat adanya nilai-nilai musyawarah mufakat juga terkandung nilai-nilai gotong royong yang dilakukan oleh tetangga sekitar ataupun kerabat demi kelangsungan dan kelancaran acara tersebut. Wujud gotong royong yang terdapat dalamacara adat sammilan ini antara lain adalah, saling membantu dari awal acara hingga selesai acara yaitu dalam proses memasak, persiapan acara adat, hingga proses acara adat sammilan ini selesai dilaksanakan, bahkan sampai terselesainya acara pernikahan.

Dalam tradisi masayrakat adat Magho Sekappung Libo, salah satu tantangan yang paling nyata dalam kehidupan sosial budaya adalah mulai memudarnya nilai-nilai biudaya dan kearifan lokal yang menjadi jati diri bangsa Indonesia. Penerimaan masyarakat terhadapbudaya baru (asing), menjadi perhatian karena 
Eka Yuliastuti dan Wahyu Abdul Jafar:

budaya tersebut membawadampak sikap apatis bagi generasi muda untuk mempelajari budayanya sendiri. Salah satu upaya untuk penguatan terhadapbudaya adat Sammilan ini adalah dengan penguatan tradisi budaya adat yang kembali digalakkan dikalangan generasi muda masyarakat adat Magho Sekappung Libo.

\section{Relefansi Aktualisasi Nilai-Nilai Kearifan Lokal Yang Terkandung Dalam Budaya Adat Sammilan \\ Dengan Nilai-Nilai Pancasila}

Segala aktifitas manusia dapat menggabungkan suatu perbuatan dengan suatu perbuatan yang berbeda dengan perbuatan yang lain untuk kemudian dapat diambil sebuah keputusan, dengan kata lain bisa dikatakan menilai atau dalamarti menimbang. Adapun keputusan yang telah ambil dapat disebut dengan nilai. Keputusan dari nilai bisa mengatakan bahwa sesuatu itu berguna atau tidak, kemudian benar atau tidak, dan baik atau tidak, serta indah atau tidak indah, religius atau tidak religius.

Lampung merupakan daerah yang memiliki kemajemukan suku dan budaya atau dapat dikatakan banyak pendatang yang menetap dan hidup di
Lampung. Seperti halnya Indonesia, dalam lingkup yang lebih sempit memiliki masyarakat yang heterogen menjadi tantangan bagi wilayah itu sendiri, terlebih Lampung masih memiliki akar budaya yang kuat. Kearifan lokal budaya masyarakat lampung tidak hanya diketahui oleh masyarakat nasional tetapijuga internasional. Sama seperti warisan budaya yang hampir tersebar diseluruh wilayah Indonesia.

Menurut Notonagoro ${ }^{15}$ Pancasila sebagai ke filsafatan, mempunyai nilainilai yang dapat dikelompokan menjadi tiga, yaitu :

- Nilai materiil, apa saja yang dapat dimanfaatkan dan sebagai bagian dari unsur jasmani manusia.

- Nilai vital, apa saja yang dapat digunakan manusia untuk dapat melakukansuatu kegiatan atau aktifitas.

- Nilai kerohanian, apasaja yang dapat digunakandalam kehidupan rohani manusia. Sementara itu, nilai kerohanian ini dapat dibedakan atasempat macam :

\footnotetext{
${ }^{15}$ Noor Ms Bakry, Pendidikan Pancasila, Pustaka pelajar,Cetakan kedua 2010,Jogja, h. 301
} 
- Nilai kebenarandidapat dari sumber unsur akal manusia (cipta) misalnyapernyataan-pernyataan dalam kajian uang bersifat bidang keilmiahan.

- Nilai kebaikan didapat dari sumber unsur kehendak manusia (karsa), misalnya kehidupan yang sejahtera.

- Nilai keindahan didapat dari sumber unsur rasa yang dimiliki oleh manusia (rasa), misalnya dapat menikmati hasil karya seni yang diciptakan oleh orang lain maupun dirinya sendiri.

- Nilai religius yang didapat dari unsur rasa kepercayaan terhadap Tuhan Yang Maha Esa (kepercayaan), dapat memenuhi perintah dari Tuhan Yang Maha Esadan menjauhi apa yang dilarang oleh tuhan Yang maha Esa.

Dinamika didalam mengaktualisasikan nilai pancasila ke dalam kehidupan bermasyarakat, berbangsa dan bernegara, harus berupa sebuah kepastian, supaya Pancasila tetap selalu relevan dengan fungsinya dalam memberikan pedoman bagi pengambilan kebijaksanaan dan sebagai pemecahan masalah dalam kehidupan bermasyarakat, berbangsa dan bernegara, supaya loyalitas warga masyarakat terhadap pancasila tetap selalu tinggi. Disisilain, supaya apatisme dan resistansi pancasila dapat diminimalisir.

Menurut Zainalabie ${ }^{16}$, warga masyarakat adat sekappung libo sendiri sejauh ini dalam melaksanakan acara adat sammilan dinilai olehnya masih selaras dan relevan dengan nilai-nilai pancasila. Walau terjadi suatu perbedaan pendapat, tetapi selalu perbedaan-perbedaan tersebut tidak menjadikan mereka lantas berselisih paham yang kemudian dapat mengakibatkan keributan. Sikap toleransi dari warga adat sekappung libo tercermin apabila ada tetangganya yang sedang melaksanakan suatu acara adat, tak segan tanpa diminta mereka akan saling menghargai, saling membantu dan saling tolong menolong.

Di era sekarang,dimana keberadaan Pancasila terus digalakkan oleh beberapa tokoh Nasional, pemuda dan masyarakat, tetapi sama sekali tidak mengurangi arti dan nilai-nilai serta relevasinya bagi kebudayaan masyarakat adat sekappung libo.

\footnotetext{
${ }^{16}$ Wawancara dengan zainal Abie, Tokoh Pemuda Negara Batin, Jabung, tanggal 18 Agustus 2019
} 
Eka Yuliastuti dan Wahyu Abdul Jafar:

Keberadaan tradisi yang lestari sudah dapat dipastikan bahwa tradisi tersebut masih bisa diterima dan tidak bertentangan dengan konsep nilai-nilai pancasila. Nilai-nilai Pancasila yang berkembang dalam masyarakat adat merupakan proses nilai yang tanpa disadari berupa cara menghargai dan menghormati keberagaman nilai adat yang berkembang dalamkehidupan masyarakat.

\section{Penutup}

Indonesia dikenal sebagai negara yang multi etnik, dimana keberadaan suku bangsa dan budaya bisa menjadi ciri khas Bangsa Indonesia. Indonesia memiliki banyak keanekaragaman budaya, adat dan istiadat. Budayabudaya yang tersebar di Indonesia adalah hasil dari kecerdasan masyarakatnya. Budaya adat sebagai bagian dari budaya nusantara sudah seharusnya dijaga dan dilestariakn oleh masyarakat selaku pemiliknya, termasuk budaya adat Sammilan. Budaya adat Sammilan mengandung banyak nilai positif yang dapat diterapkan dalam menjalani kehidupan bermasyarakat maupun bernegara,karena masih selaras dengan nilai-nilai Pancasila yang ada dan berlaku serta masih diterapkan oleh warga msayarakat adat di esa Negara Batin. Karena pada hakikatnya, budaya adatSammilan hadir ditengah-tengah masyarakat yang masih sangat menjaga dan memelihara Indonesia dalam berbagai aspek kehidupan.

Saat ini ancaman memudarnya nilainilai budaya adat tidak hanya datang dari dalam negeri tetapi juga dari luar negeri. Ancaman dari luar lebih kepada bentuk upaya untuk menghancurkan moral dan budaya bangsa melalui disinformasi, propaganda, hedonisme, meterialisme, konsumerisme atau berbagai kegiatan budaya asing yang mempengaruhi budaya bangsa. Budaya adat Sammilan diharapkan akan terus tetap bisa tumbuh, berkembang dan lestari serta tidak bertentangan dengan nilai-nilai falsafah Pancasila.

\section{Pustaka Acuan}

Aji, Gunggung Seno. Kearifan Lokal Masyarakat Baduy Dalam Mengelola Hutan dan Lingkungannya, Tesis S2 Ilmu Kehutanan. UGM.Yogyakarta, 2003.

Arifin, Samsul. Studi Agama; Perspektif Sosiologi dan Isu-Isu Kontemporer, Malang: UMM Press, 2009.

Ariyanto, Imran Rachman, Bau Toknok. Kearifan Masyarakat Local Dalam 
Pengelolaan Hutan di Desa Rano Kecamatan Balaesang Tanjung, Kabupaten Donggala, Warta Rimba, Vol.2 No 2, Desember 2014

Cooley, Frank L. Mimbar dan Tahta, Jakarta: Pustaka Sinar Harapan, 1987

Ernawi, (2010), Harmonisasi KearifanLokal Dalam Regulasi PenataanRuang,(Online), Makalah PadaSeminar Nasional 'UrbanCulture,Urban Future, HarmonisasiPenataan Ruang dan Budaya UntukMengoptimalkan Potensi Kota, padahttp://www.penataanruang.net, ( 26Desember 2013)

Francis, Wahono. 2005. Pangan, Kearifan Lokal dan Keanekaragaman Hayati. Cindelaras Pustaka Rakyat Cerdas. Yogyakarta.

Geertz, ,Kebudayaan dan Agama, Kanisius Press, Yogyakarta, 1992.

Gusmansah, Wery. Triaspolitika dalam perspektif fiqh syiasah, Jurnal Imaroh, Vol 2 No 2 Tahun 2017, h.124

Haba, John. "Revitalisasi Kearifan Lokal: Studi Resolusi Konflik di Kalimantan Barat, Maluku, dan Poso", dalam Irwan Abdullah dkk. (ed.), Agama dan kearifan Lokal Dalam Tantangan Global, Yogyakarta: Pustaka Pelajar, 2008.

Hendriyana, Metodologi Kajian Artefak Budaya Fisik (FenomenaVisual Bidang Seni), Bandung,Sunan Ambu, 2009.
Hidayati, Deny. Memudarnya Nilai Kearifan Local Masyarakat Dalam Pengelolaan Sumber Daya Air, Jurnal Kependudukan Indonesia, Vol.11 No 1, Juni 2016

Indriastjario, Bambang Aji murtono. Kajian Kearifan Local Untuk Pengembangan Wisata Waduk Jati Barang Kota Semarang, Jurnal Modul, Vol.15 No.2 Juli-Desember 2015

Irham, Muhammad Aqil. Falsafah Piil Pesenggiri dan Kehidupan Keagamaan Masyarakat Etnis Lampung Pepadun dalam Menghadapi Transformasi Budaya Global (Studi Hubungan Nilai-nilai Budaya dan Agama), Bandar Lampung: Puslit IAIN Raden Intan Lampung, 1997.

Irianto, Sulistyowati. "Piil Pesenggiri; Modal Budaya dan Strategi Identitas Lampung",Jurnal Sosial Humaniora, Vol. 15.No. 2, 2004.

Kurtz, LesterGods in the Global Village, California-London-New Delhi: Pine Forge Press, 1995.

Mudzhar, M. Atho. "Pluralisme, Pandangan Ideologis, dan Konflik Sosial Bernuansa Agama", dalam Moh. Soleh Isre, Konflik Etno Religius Indonesia Kontemporer, Jakarta: Puslitbang Kehidupan Beragama, 2003.

Nurdin, A. Fauzie. Budaya Muakhi, Yogyakarta: Gama Media, 2009.

Parson, Talcott."Teori Sistem Umum: Suatu Gerakan ke Arah Kesatuan Teori Ilmu Perilaku”, dalam Margareth M. Poloma (ed), 
Sosiologi Kontemporer, terj. Yasogama, Jakarta: Rajawali Pers, 2010.

Ratnawati, Pengkajian Nilai-Nilai Luhur Budaya Spiritual Bangsa Daerah Lampung, Jakarta: Departemen Pendidikan dan Kebudayaan, 1992 .

Ritzer, George dan Douglas J. Goodman. Teori Sosiologi Modern, terj. Alimandan, Jakarta: Kencana, 2012.

Sudjangi (Peny.), Profil Kerukunan Hidup Umat Beragama; Bingkai Sosio-Kultural Kerukunan Hidup Antar Umat Beragama di Indonesia, Jakarta: Balitbang Agama, 1997.

Sugiyono, Analisis Data Kualitatif. Penerbit Universitas Indonesia.,2011

Sularso, Revitalisasi Kearifan Local Dalam Pendidikan Dasar, Jurnal Pendidikan sekolah dasar. Vol 2 No 1, Desember 2016

Suyatno, Suyono. "Revitalisasi Kearifan Lokal Sebagai Upaya Penguatan IdentitasKeindonesiaan", dalamhttp: //badanbahasa.kemdikbud.go.id/lam anbahasa/artikel/1336

Syani, Abdul. ,Menumbuhkan Kembali Nasionalisme Melalui Nilai-Nilai kearifan Local,

Zarkasi, Ahmad. Islam dan Budaya Lampung (Aktualisasi Nilai-Nilai Budaya Lokal), Bandar Lampung: Aura Puslishing, 2014. 